\title{
Sosyal Sermayenin Ekonomik Büyüme Üzerindeki Potansiyel Etkisi: Türkiye İçin Yapısal Kırılmalı Eşbütünleşme Analizi
}

Oktay KIZILKAYA, Department of Economics, Ahi Evran University, Turkey; e-mail: okizilkaya@ahievran.edu.tr

\section{The Potential Effect of Social Capital on Economic Growth: Structural Fractured Cointegration Analysis for Turkey}

\begin{abstract}
The impact of the trust factor on economy has been a longstanding debate in the economic literature. Recently, investigating the impact of social capital, which represents trust, on economic growth has become an attractive research area. In this context, the study examines the relationship between social capital indicators and economic growth over the period 2006-2014 using quarterly data. We use Principal Components Analysis method to calculte the social capital index. In the next phase, the effect of social capital index, labour force participation rate and fixed capital on economic growth is investigated by using Maki (2012) cointegration test with structural breaks and Stock-Watson (1993) DOLS estimation methods. Analysis results show that social capital has a positive impact on economic growth.
\end{abstract}

Keywords

Social Capital, Trust, Economic Growth, Structural Break Cointegration Test, DOLS Estimation Method, Turkey.

JEL Classification Codes : $\quad \mathrm{O} 15, \mathrm{O} 47, \mathrm{O} 11, \mathrm{O} 12$.

\section{$\ddot{\mathbf{O} z}$}

Ekonomi literatüründe güven faktörünün ekonomiler üzerindeki etkisi uzun yıllardır süregelen bir tartışmadır. Son yıllarda ise güveni temsil eden sosyal sermayenin ekonomik büyüme üzerindeki etkisi literatürde ilgi gören bir araştırma alanı haline gelmiştir. Bu kapsamda, çalışmada Türkiye Ekonomisi için sosyal sermaye göstergeleri ve ekonomik büyüme ilişkisi 2006-2014 çeyrek dönemlik veriler ile incelenmiştir. Analiz için öncelikle Temel Bileşenler Analiz (TBA) yöntemi ile sosyal sermaye endeksi hesaplanmıştır. Sonraki aşamada sosyal sermaye endeks, işgücüne katılım oranı ve sabit sermayenin ekonomik büyüme üzerindeki etkisi Maki (2012) yapısal kırılmalı eşbütünleşme testi ve Stock-Watson (1993) DOLS tahmin yöntemi ile incelenmiştir. Analiz sonuçları sosyal sermayenin ekonomik büyüme üzerinde pozitif bir katkısı olduğunu işaret etmektedir.

Anahtar Sözcükler $\quad$ : Sosyal Sermaye, Güven, Ekonomik Büyüme, Yapısal Kırılmalı Eşbütünleşme Testi, DOLS Tahmin Yöntemi, Türkiye. 
Kızılkaya, O. (2017), "Sosyal Sermayenin Ekonomik Büyüme Üzerindeki Potansiyel Etkisi:

Türkiye İçin Yapısal Kırılmalı Eşbütünleşme Analizi”, Sosyoekonomi, Vol. 25(33), 175-194

\section{Giriş}

Ekonomistler arasında bir ülkenin ekonomik büyümesinde sosyal sermayenin etkisine yönelik çalışmalar artarak devam etmektedir. Sosyal sermaye ile ekonomik büyüme arasındaki ilişkiyi analiz eden çoğu çalışma ile birlikte araştırmacıların ekonomik büyümenin sermaye, işgücü ve doğal kaynaklar gibi geleneksel faktörler tarafından etkilendiği düşüncesi ortadan kalkmaktadır. Bu nedenle günümüzde sosyal sermayenin ekonomik büyüme üzerindeki etkisi önemli bir tartışma konusu olmuştur. $\mathrm{Bu}$ tartışmanın ana kaynağı, sosyal sermaye ile ekonomik büyüme arasındaki ilişkiye ilk kez değinilen ve 1993 yılında Putnam vd. tarafından yayımlanan "Making Democracy Work" adlı çalışmadır. Putnam vd. (1993), çalışmada İtalya'yı iki bölgeye ayırarak sosyal sermaye ile bölgelerin ekonomik gelişmişliklerini karşılaştırmış ve sosyal sermayesi daha yüksek olan bölgenin ekonomik olarak daha hızlı büyüdüğünü ifade etmiştir. Putnam vd. (1993), sosyal sermayeyi işbirliği eylemlerini kolaylaştırarak toplumun verimliliğini artırabilen güven, normlar ve ağlar gibi toplumsal örgütlenme özellikleri olarak tanımlamaktadır. Sosyal sermaye kavramının gelişimine katkı sağlayan diğer bir araştırmacı James Coleman'dır. Coleman (1990), sosyal sermayeyi bireyler arasındaki kurumsal ilişkiler olarak tanımlamaktadır.

Ekonomistler makro değişkenlere ilaveten sosyal sermaye faktörünü de ekonominin gelişmesinde önemli bir açıklayıcı unsur olarak görmektedir. Fukuyama (1995a), Putnam vd. (1993) gibi sosyal sermayenin ekonomik performans üzerindeki etkisine vurgu yapmaktadır. Fukuyama (1995a), gelişmiş ekonomilerde başarılı bir ekonomik performans için genelleştirilmiş güven olarak ifade ettiği sosyal sermayenin önemli olduğunu savunmaktadır. Putnam vd. (1993), sosyal sermayede norm ve ağların rolüne vurgu yaparken, Fukuyama (1995a) güvenin rolünü önemsemektedir. Putnam vd. (1993) ve Fukuyama (1995a, 1995b) çalışmalarında sosyal sermayenin ekonomik büyüme üzerinde pozitif etkisi olduğunu savunmaktadır. Fakat bu çalışmalardaki tezleri ampirik olarak destekleyen analizlerin yetersiz olduğu görülmektedir (Paldam \& Svendsen, 2000: 340; Beugelsdijk \& Schaik 2005: 305). Bunun en önemli sebebi sosyal sermayenin ampirik olarak ölçülmesinin zor olması gerçeğidir (Salahuddin vd., 2015: 943). Sosyal sermaye konusunda literatürde kullanılan göstergeler sıklıkla güven ve örgütsel etkinlik kavramları üzerinedir. $\mathrm{Bu}$ göstergeler daha çok Dünya Değerler Anketinden (World Values Surveys) alınan ve mikro sosyal sermaye için kullanılan göstergelerdir (La Porta vd. 1997: 333; Knack \& Keefer, 1997: 1255). Bu nedenle literatürde sosyal sermaye mikro ve makro olmak üzere iki çerçevede ele alınmaktadır. Mikro sosyal sermaye, genel olarak grup içindeki sosyal sermayeyi temsil ederken; makro sermaye kamusal düzeyde gerçekleşen sosyal sermayeyi temsil etmektedir. Literatürde makro sosyal sermaye için kullanılan göstergeler bulunmaktadır. Bunlar demokratik hesap verilebilirlik, demokrasiye katılım, sözleşmelerin uygulanabilirliği, ekonomik risk değerlendirmesi, finansal risk değerlendirmesi, hükümet istikrarı, hukuk düzeni, hukukun üstünlüğü, yönetim biçimleri, kurumların nitelikleri ve politik risk değerlendirmesi şeklinde sıralanabilir. Yasaların güvenliği, düşük yolsuzluk düzeyi, şeffaflık, yönetim sistemlerinin etkinliği, hükümetlerin yeterliliği ve kredibilitesi yine makro sosyal sermaye kapsamında değerlendirilmektedir. Bu göstergeler, bir ülkede sağlanması gereken güven faktörünün makro düzeyindeki temsilcileridir. Bu nedenle makro sosyal sermayenin ekonomik performans ile doğrudan ilişkili olduğu söylenebilmektedir. 
Bu çalışmanın odak noktası özel bir kuruluş olarak uluslararası yatırım riski hizmeti veren International Country Risk Guide (ICRG) tarafindan derlenen kurumsal gösterge verileridir. Çalışmada Mauro (1995) ile Knack ve Keefer'in (1995) de ele aldıkları gibi sosyal sermayenin göstergeleri olarak kabul edilen ICRG verileri kullanılmıştır. ICRG verileri ülkelerin kurumsal sistemlerini çok boyutlu olarak inceleyen oranlardır. Bu oranlar literatürde makro sosyal sermayenin göstergeleri olarak kabul edilmektedir (Mauro 1995: 684; Knack \& Keefer 1995: 222; Kormendi \& Meguire 1985: 142).

Literatürde sınırlı sayıdaki ampirik çalışma sosyal sermayenin ekonomik gelişme/büyüme üzerinde önemli bir etkisi olduğunu ortaya koymaktadır. (Knack \& Keefer, 1997: 1251; Temple \& Johnson, 1998: 965; Whiteley, 2000: 443; Annen, 2003: 449; Casey \& Christ, 2005: 826; Berggren, vd. 2008: 251). Buna ilaveten, Türkiye'de sosyal sermayenin ekonomik büyüme üzerindeki etkisine yönelik literatürde bir araştırma boşluğu gözlemlenmiştir. İlgili boşluktan hareketle bu çalışma, Türkiye'de sosyal sermayenin ekonomik büyüme üzerindeki etkisini gelişmiş zaman serisi yöntemleri ile geleneksel üretim fonksiyonu kapsamında araştırmayı hedeflemiştir. Çalışmanın literatüre katkısı ve önemi iki yöndedir. i) Araştırma sonucunda elde edilen bulguların ekonomi politikalarına yön vermesi beklenmektedir. ii) Yöntem olarak son dönemlerde Maki (2012) tarafından geliştirilen ve yapısal kırılmaları dikkate alan eşbütünleşme testi ve uzun dönem katsayı tahmininde Stock ve Watson (1993) dinamik en küçük kareler yöntemi (DOLS) kullanılmıştır. Bilindiği kadarıyla bu çalışma, ilgili yöntemleri kullanarak sosyal sermayenin ekonomik büyüme üzerindeki etkisini inceleyen literatürdeki ilk çalışmadır.

Bu çalışma üç bölümden oluşmaktadır. Birinci bölümde sosyal sermayeyi kavramsal olarak ele aldıktan sonra sosyal sermaye ile ekonomik büyüme arasındaki teorik ilişki açıklanacaktır. İkinci bölümde ise sosyal sermaye ile ekonomik büyüme arasındaki ilişkiyi ampirik olarak analiz eden mevcut literatüre yer verilecektir. Üçüncü bölümde sosyal sermaye ile ekonomik büyüme arasındaki ilişki çeyrek dönem verileri ile ampirik olarak sınanacaktır. $\mathrm{Bu}$ bölümde model, veri seti, yöntem ve ekonometrik bulgulara yer verilecektir. Çalışmanın sonuç kısmında ise elde edilen bulgular çerçevesinde bazı tespitlerde ve politika önermelerinde bulunulacaktır.

\section{Teorik Altyapı}

\subsection{Sosyal Sermayenin Kavramsal Boyutu}

Sosyal sermaye kavramı son yıllarda popülerlik kazansa da ilk kullanıldığı dönem 20. yy'nin ilk yıllarına denk gelmektedir. "Sosyal sermaye" terimini ilk kez Lyda Hannifan 1916 yılında yayınladığı kitapta kullanmıştır. Hannifan (1916), sosyal sermayeyi; günlük hayatta sosyal yapıyı oluşturan insanların bireyler ve aileler arasında karşılaştığı iyi niyet, kardeşlik, sempati ve sosyal bağlantı gibi maddi olmayan değerler olarak tanımlamıştır. Zaman içerisinde sosyal sermaye kavramı araştırmacılar tarafindan farklı şekillerde tanımlanmıştır. Fakat herkesin uzlaştığı bir sosyal sermaye tanımından bahsetmek mümkün değildir. Coleman $(1988,1990)$ göre; sosyal sermaye sosyal yapı içindeki bireylerin veya kurumsal aktörlerin belirli eylemlerini kolaylaştıran oluşumlardır. Coleman (1988), sosyal 
sermayeyi "yükümlülükler ve beklentiler ile bilgi kanalları ve sosyal normlar" olarak tanımlar. Fukuyama (1995, 1999, 2002), sosyal sermayeyi gruplardaki ve organizasyonlardaki insanların ortak amaçları için beraber hareket edebilme yetisi, gruplarda bireyler arası işbirliğine izin veren normlar veya resmi olmayan değerler bütünü olarak ifade etmektedir. Bu düşünceye göre sosyal sermaye, bireylerin bir araya gelmelerini, çıkarlarını savunmalarını ve topluluk ihtiyaçlarının giderilmesi için organize olmalarını sağlayan araçtır. Dünya Bankası (1998), sosyal sermayenin, bir toplumun kişiler arasındaki etkileşimleri yöneten kurumları, ilişkileri, davranışları ve değerlerini içermekte olduğunu ve sosyal sermayenin ekonomik ve sosyal kalkınmaya yardımcı bir faktör olarak ifade etmektedir. Ayrıca bu tanıma göre; sosyal sermaye, sadece toplumu destekleyen kurumların bir toplamı değil aynı zamanda onları bir arada tutma görevi üstlenmektedir. Dahası, kişisel ilişkileri, güveni ve toplumu bireylerin toplamından daha fazlası biçiminde ele alan yurttaş sorumluluğuna yönelik değerleri ve kuralları içermektedir. OECD (2001), sosyal sermayeyi, toplumu oluşturan fertler, sivil toplum örgütleri ve kamu kurumları arasındaki koordinasyon faaliyetlerini kolaylaştıran toplumun üretkenliğini artıran, güven, norm ve iletişim ağ özellikleri biçiminde açıklarken; iktisadi açıdan sosyal sermayeyi de kişi ve kurumlar arası güvene dayalı ilişkilerin, ekonomik etkinliğine ve üretime yansıması olarak kabul etmektedir.

Sosyal sermaye ekonomi dişında diğer disiplinlerle ilişkisi olan bir kavramdır. Şimdiye kadar literatürde hemen hemen her disiplinden yapılan tanımları görmek mümkündür. Ekonomik büyümeyi ya da üretimi artırmakla doğrudan / dolaylı etkisi olduğu düşünülen sosyal sermaye ilişkin yapılan diğer tanımlar kronolojik olarak aşağıdaki tabloda verilmiştir.

\section{Tablo: 1}

\section{Sosyal Sermaye Tanımları}

\begin{tabular}{|c|c|c|}
\hline Yazar & Yll & Sosyal Sermaye Tanımı \\
\hline Lolury, Glenn & 1977 & Standart beşeri sermaye kazanımını arttıracak sosyal durumlar ve sonuçlardır. \\
\hline Baker, Wayne & 1990 & $\begin{array}{l}\text { Bireylerarası ilişkilerdeki farklılıklar vasıtasıyla oluşan, bireylerin belirli sosyal yapılardan elde ettikleri ve } \\
\text { kendi çıkarları doğrultusunda kullandıkları kaynaktır. }\end{array}$ \\
\hline $\begin{array}{l}\text { Bourdieu, Pierre ve Wacquant, } \\
\text { Loic }\end{array}$ & 1992 & $\begin{array}{l}\text { Güvenilir bir ağa sahip olma neticesinde, sahip olunan ağın kurumsallaşmasına göre az veya çok kazanım } \\
\text { veya tanınma sağlayan gerçek veya sanal kaynakların tamamıdır. }\end{array}$ \\
\hline $\begin{array}{l}\text { Portes, Alejandro ve } \\
\text { Sensenbrenner, Julia }\end{array}$ & 1993 & $\begin{array}{l}\text { Ekonomik hedefleri ve topluluktaki üyelerin ekonomik çerçeveye dahil olmayan davranışlarını etkileyen } \\
\text { hareketler ve beklentilerdir. }\end{array}$ \\
\hline Putnam, Robert vd. & 1993 & Güven, norm ve ağ gibi koordineli eylemleri hızlandıran sosyal organizasyon özellikleridir. \\
\hline Whiteley, Paul F. & 2000 & İnsanların kendi aile üyelerine, yurttaşlarına ve genel olarak da diğer kişilere güvenmek istemeleridir. \\
\hline $\begin{array}{l}\text { Woolcock, Micheal ve } \\
\text { Narayan, Deepa }\end{array}$ & 2000 & İnsanların birlikte hareket etmelerini sağlayan normlar ve ağlardır. \\
\hline Putnam, Robert & 2001 & Sahip olunan bireyler için bir değer teşkil eden ve pozitif dışsallıklar sağlayan oluşumdur. \\
\hline Sciarrone, Rocco & 2002 & $\begin{array}{l}\text { Bireyin ağlardaki pozisyonu gereği gerçekleşen sosyal ilişkileri sonucunda ortaya çıkan kaynakların } \\
\text { tamamıdır. }\end{array}$ \\
\hline Bjornskov, Christian & 2003 & Genelleştirilmiş güvendir. \\
\hline Grootaert, Christiaan vd. & 2004 & İnsanların üretim amaçları için sahip oldukları gruplar, ağlar, normlar ve güven duygusudur. \\
\hline Miguel, Edward vd. & 2006 & $\begin{array}{l}\text { Gönüllü toplulukların güven düzeyinin, resmi olmayan işbirliklerinin ve derneksel aktivitelerinin } \\
\text { yoğunluğudur. }\end{array}$ \\
\hline Lin, Nan & 2008 & Bireylerin sosyal ağlarında mevcut olan, yine ağlar vasıtasıyla ulaşılabilen kaynaklardır. \\
\hline Hayami, Yujiro & 2009 & Ekonomik aktörler arasındaki sosyal ilişkiler sonucunda ortaya çıkan sosyal üründür. \\
\hline Sabatini, Fabio & 2009 & Gruplara üyelik ve sosyal bağlar vasıtasıyla elde edilen kaynaklardır. \\
\hline
\end{tabular}




\subsection{Sosyal Sermaye Çeşitleri}

Sosyal sermaye konusunda sınıflandırmaya giden ilk araştırmacının Putnam (2000) olduğu kabul edilmektedir. i) Bağlayıcı ve ii) Köprü Kuran olmak üzere sosyal sermayeyi iki kategoride incelemişstir. Woolcock (2001), yaptığı katkıyla iii) Birleştirici sosyal sermayeyi sınıflandırmaya dahil etmiştir. Sonrasında yapılan pek çok çalışmada belirtilen bu üçlü sınıflandırma kullanılmıştır. Bă̆layıcı sosyal sermaye; aile, yakın arkadaş ve ortak kültür veya etnik grup gibi benzer bir kimlik duygusunun paylaşıldığı insanlarla "bizden birileri” olan ilişkiler olarak tanımlanmıştır. Üç kategorideki en güçlü ilişkilerin bu grupta olduğu kabul edilmektedir. Bu gruplarda bireyler güçlü yakınlık bağı kurmakta ve topluluk bağına sahip çıkmaktadırlar. Băğlayıcı sosyal sermayeye sahip gruplar daha çok akrabalık, din, mezhep, etnik köken, sınıf/kast, cinsiyet veya coğrafi temelde oluşurlar ve piyasa ile ilişkileri de yine bu çerçevede farklılaşır (Çalışkan, 2010: 14). Ulusal bazda ortaya çıkan buhran ve benzeri durumlarda etkin bir şekilde kullanıldığı takdirde bağlayıcı sosyal sermaye sorunların giderilmesinde etkili olabilmektedir (Knorringa \& Staveren, 2006: 43). Köprü kuran sosyal sermaye; yakın olmayan arkadaşlar, iş arkadaşları ve dostlarla olan ilişkiler olarak tanımlanmaktadır. Heterojen gruplar arası iletişime katkıda bulunarak güvenin oluşmasına zemin hazırlamaktadır. Bağlayıcı sosyal sermayeye oranla içinde bulunulan grup veya bireylerde daha uzak ilişkiler mevcuttur. Bağlayıcı sosyal sermayenin tersine farklı bölgelerde yaşayan insanların ve grupların arasındaki ilişkiyi inceleyen köprü kuran sosyal sermaye, bölgesel farklılıkları göz ardı ederek kazanımların artmasına ve bölgelerin gelişmesine katkı sağlamaktadır (Özcan, 2011: 29). Birleştirici sosyal sermaye ise sosyal statü olarak bireyden daha aşağıda veya yüksekte olan birey veya gruplarla olan ilişkiler ifade edilmektedir. Güç ve statü gibi toplumda sınıf ayrılıklarına yol açan kavramlar bu sosyal sermaye türü için belirleyici olmaktadır (Healy \& Cote, 2001: 24).

Collier (1998) ise sosyal sermayeyi hükümet sosyal sermaye ve sivil sosyal sermaye olarak sınıflandırmıştır. Hükümet sosyal sermayeden ortak fayda için insanların işbirliği yapma yeteneğini etkileyen kamu kurumları kastedilmektedir. Bu kurumların yapmış oldukları sözleşmelerin uygulanabilirliği, hukukun üstünlüğü ve devlet tarafindan izin verilen sivil özgürlüklerin kapsamı hükümet sosyal sermaye içinde değerlendirilmektedir. Sivil sosyal sermaye ise ortak değerleri, normları, resmi olmayan ağları ve ortak amaçlara ulaşmak için beraber hareket eden bireylerin yeteneğini etkileyen dernek üyeliklerini kapsamaktadır. Her iki tip sosyal sermayenin amacı toplum olarak beraber hareket edememe sorunun üstesinden gelerek sosyal düzenin sağlanmasına yardımcı olmaktır (Knack 2002: 2).

Sosyal sermaye yukarıda verilen sinıflandırmalar haricinde mikro(sivil) ve makro(kamusal) düzeyde de sinıflandırılmaktadır. Mikro sosyal sermaye genel olarak topluluk içinde oluşan sosyal sermayeyi temsil ederken; makro sermaye kamusal düzeyde gerçekleşen sosyal sermayeyi temsil etmektedir. Tanım gereği mikro sosyal sermaye bağlayıc1, köprü kuran ve birleştirici sosyal sermayeyi de kapsamaktadır (Parts, 2003: 24). Mikro sosyal sermaye işbirlikçi normları, kişilerarası güveni ve sosyal ağları içermektedir. Mikro ve makro sosyal sermayenin, birbirlerini tamamlayıcı ya da ikame edici oldukları kabul edilmektedir (Özcan, 2011: 30). Makro sosyal sermaye, ulusal ve uluslararası düzeyde 
gerçekleşen sosyal sermayeyi kapsamaktadır. Demokrasi, hukukun üstünlüğü, demokrasiye katılım, yönetim biçimleri, geleneksel ve çağdaş değerler, kurumların nitelikleri makro sosyal sermaye olarak değerlendirilmektedir (Akçay, 2005: 202; Ekşi, 2009: 36). Yasaların güvenliği, yolsuzlukların azalması, şeffaflık, yönetim sistemlerinin etkinliği, hükümetlerin yeterliliği ve kredibilitesi yine makro sosyal sermaye kapsamında değerlendirilmektedir (Parts, 2003: 25). Bu nedenle makro sosyal sermayenin ekonomik performans ile doğrudan ilişkili olduğu söylenebilmektedir. Ayrıca makro sosyal sermaye, ulusal seviyede kanuni hüküm değerlerini ve kolektif eylemi hızlandırmada resmi kurumların etkinliğini ölçmeyi amaçlamakta ve sivil özgürlük, politik özgürlük, politik şiddetin sıklığı ya da politik risklerin öznel sınıflandırmalarını içeren bir takım değişkenlerle temsil edilmektedir.

Sosyal sermayenin üçüncü sınıflandırılma şekli yapısal ve bilişsel olarak gerçekleştirilmektedir. Bu ayrım Uphoff (2002) tarafından yapılmıştır. Yapısal sosyal sermaye genel itibariyle sosyal organizasyonların biçimleri ile ilişkilendirilmektedir. Bunlar roller, kurallar, prosedürler, iş birliği ve kolektif eylemlere fayda sağlayan ağ kümeleridir. Bilişsel sosyal sermaye ise zihinsel araçlardan türeyen, kültür tarafından katkı sağlayan normlar, tutumlar ve değerler olarak ifade edilebilmektedir. Bilişsel sosyal sermaye genel itibariyle daha öznel konuları içerirken, yapısal sosyal sermayeye nesnel içerikli konular dâhildir.

\subsection{Sosyal Sermaye ile Ekonomik Büyüme Arasındaki İlişki}

Sosyal sermaye ekonomi alanında nispeten yeni bir çalışma alanıdır. Yeni bir çalışma alanı olması ise sosyal sermayenin daha çok ekonomik gelişme ile ilişkilendirilmesi gibi durum ortaya çıkarmaktadır. Literatüre bakıldığında kalkınma, yoksulluk ve gelir dağılımı gibi konularla ilişkilendirilen çalışmalar da mevcuttur. Bununlar beraber sosyal sermaye ile ilgili teorik literatür oldukça geniştir. Bu konuyla ilgili teorik literatürün bir kısmı çalışmanın kavramsal boyutunda verilmiştir. Bu bölümde ise sosyal sermaye ile ekonomik büyüme arasındaki teorik literatür hakkında bilgi verilecektir.

Ekonomistler sosyal sermayenin ekonominin gelişmesinde önemli açıklayıcı bir faktör olarak görmüşlerdir. Fukuyama'ya (1995a) göre; sosyal sermayenin bir formu olan genelleştirilmiş güvene sahip toplumlar küresel ekonomik rekabette başarılarına katkı sağlamaktadır. Genelleştirilmiş güven, bir topluluk üyeleri tarafından içselleştirilmiş bir dizi etik alışkanlık ve karşılıklı ahlaki yükümlülüklere dayanmaktadır (Beugelsdijk \& Schaik, 2005: 310). Fukuyama (1995a), yüksek güvenin olduğu toplumlarda daha az yasal düzenlemelere ve zorlayıcı yaptırım mekanizmalarına başvurulduğunu iddia etmektedir. $\mathrm{Bu}$ düşünceye göre; güven faktörü sosyal yaşamda iş sözleşmelerine alternatif bir faktördür. Kurumsal sistem düzgün bir şekilde işlediği zaman güven sadece karmaşık işlemleri kolaylaştıran bir faktör olarak görülmelidir. Bu durum işlem maliyetlerini düşürmekte dahası ekonomik gelişmeye katkı sağlamaktadır. Fukuyama'ya (1995a) göre; genelleştirilmiş güven gelişmiş ekonomilerde başarılı bir ekonomik performans için gereklidir. Güven, gücün ve piyasanın doğrudan etkisi olmaksızın işbirliği sağlar. Bu yüzden güven sadece hukuki sistemlerde bir alternatif olarak hizmet etmemekte, aynı zamanda iyi işleyen bir kurumsal sistemde bile sözleşmelerin düzenlenmesinde karmaşık işlemleri kolaylaştıran bir 
faktör olarak önem arz etmektedir. Diğer bir deyişle, ekonomik sistemde iyi işleyen kurumların varlığında bile bazı işlemler güven yokluğunda neredeyse imkansız olabilmektedir. Ayrica bu görüşe göre güvenin yüksek olduğu toplumlardaki organizasyonlarda yeni teknolojiler daha etkin uygulanabilir ve bu şekilde verimlilik artırılabilir (Knack, 1999: 5).

Knack (1999), sosyal sermayenin ekonomik performansı mikroekonomi ve makro politikalar olmak üzere iki kanal aracılığıyla etkilediğini savunmaktadır. Mikro düzeyde sosyal bağlar ve kişilerarası güven işlem maliyetlerini azaltırken, sözleşmelerin uygulanabilirliğini sağlamakta ve bireysel yatırımcılar düzeyinde kredileri kolaylaştırabilmektedir. Sosyal bağlar ve toplumda sağlanmış olan güven bir ülkede yürürlükte olan mülkiyet ve sözleşme haklarına benzetilmektedir. Mülkiyet ve sözleşme hakları gibi güven faktörü de piyasadaki belirsizliği ve işlem maliyetlerini azaltmaktadır (Knack, 2002: 7). Almond ve Verba (1963), makro düzeyde sosyal uyum ve sivil uzlaşının demokratik yönetimleri güçlendirdiği, Putnam vd. (1993) sosyal sermayenin kamu yönetimindeki etkinliği ve liyakatı geliştirdiği, Easterly ve Levine (1997) ise sosyal sermayenin ekonomik politikaların kalitesini artırdığını vurgulamaktadır. Helliwell ve Putnam (1995), ekonomik büyüme konusunda kurumsal performansın etkilerini vurgularken bu performansın ölçülmesinde sivil toplum ve vatandaş memnuniyeti gibi alternatif unsurları önermektedir. Zak ve Knack (2001), yüksek güvenin olduğu toplumlarda yatırımların ve büyümenin de yüksek olabileceğini ve gelir dağılımındaki eşitliğin toplumdaki güveni artırabileceğini savunmaktadır.

\section{Ampirik Literatür}

Sosyal sermaye ile ekonomik büyüme arasında ilişki ampirik olarak ilk kez Kormendi ve Meguire'nin 1985 yılında yapmış oldukları çalışmada analiz edilmiştir. Kormendi ve Meguire'in (1985) yapmış oldukları çalışma, istatiksel bir yaklaşım kullanılarak 47 ülkede ekonomik performans ile hükümet sosyal sermaye arasındaki ilişkiyi ilk olarak araştıran çalışmalar arasındadır. Sivil özgürlüklerin sosyal sermayenin önemli bir göstergesi olarak alındığı çalışmada, sivil özgürlüklerin GSYİH içindeki yatırım miktarını açıklamada güçlü bir faktör olduğunu ve yüksek sivil özgürlüklerin GSYİH içindeki yatırım miktarını yaklaşık olarak \%5 oranında artırdığı gözlenmiştir.

Sosyal sermaye konusundaki diğer ampirik literatüre bakıldığında sosyal sermaye göstergesi olarak güven, norm ağlar ile örgütsel etkinlik (Putnam 1993) ve güvenin (Knack \& Keefer, 1997) üzerinde durmaktadır. Putnam (1993), sosyal sermayenin bir göstergesi olarak grup üyeliğini kullanmış ve Kuzey İtalya'nın sosyal sermayesi daha yüksek olduğundan Kuzey İtalya'nın Güney İtalya'dan daha hızlı geliştiğini ifade etmiştir. Putnam (1993)'a göre, ekonomik ve kurumsal performanstaki bölgesel farklılıklar sosyal sermayenin gelişimine önemli oranda katkı sağlamaktadır. Knack ve Keefer (1997), resmi gruplara üyelik konusunda bir kanıt bulmamakla birlikte güven, sivil normlar ve gelir arasında güçlü bir ilişki bulurken ve ekonomik performans ile güvenin ilişkili olduğu sonucu elde edilmiştir. Ayrıca Knack ve Keefer (1997), sözleşme ve mülkiyet haklarını etkili bir 
şekilde koruyan resmi kurumlara sahip olan ülkelerde güven göstermek ve sivil normlar daha güçlü olduğunu ifade etmişlerdir.

Annen (2001), sosyal sermayenin düşük yürütme maliyetleri ve ticarette yüksek kazançlar vasıtasıyla ekonomik büyümeyi olumlu etkilediği sonucuna ulaşmıştır. Routledge ve Amsberg (2003), çalışmada ekonomik büyümeyi doğrudan etkileyen teknolojik gelişmenin, sosyal sermayeyi işgücünün yeniden dağılımı yoluyla etkilediği sonucuna ulaşarak sosyal sermaye ile büyüme arasında dolaylı bir ilişki tespit edilmiştir. Casey (2004), İngiltere'deki bazı bölgeler için 1990-1998 dönemini baz aldığı çalışmada sosyal sermayenin bileşenlerinden olan sivil kuruluşlara katılım ve bu kuruluşlarda rol almanın ekonomik büyüme üzerinde pozitif etkisi olduğu tespit edilirken iktisadi kuruluşlarda rol almanın ekonomik büyüme üzerindeki etkisi bulunamamıştır. Beugelsdijk ve Schaik (2004), 54 AB bölgesi için yaptıkları analizde 1950-1998 döneminde Avrupa'daki bölgesel büyüme farklılıklarının sosyal sermaye ile ilişkili olduğu sonucuna ulaşmışlardır. Casey ve Christ'in (2005) yapmış olduğu çalışma 48 ABD eyaletinde 1977-2001 yılları arasında sosyal sermayenin ekonomik eşitlik ve istihdam üzerinde önemli etkilerinin olduğunu göstermektedir. Ponzetto ve Troiano (2014), sosyal sermayenin beşeri sermayeyi teşvik eden üretken kamu yatırımları vasıtasıyla ekonomik büyümeyi olumlu etkilediği sonucuna ulaşmıştır. Sakai (2012), sosyal sermaye faktörlerinin (güven, norm, ağ gibi) orta dönem ekonomik büyüme üzerinde hem olumlu hem de olumsuz etkilerinin olduğunu göstermektedir.

İlgili literatür incelendiğinde sosyal sermaye ile ekonomik büyüme arasında negatif ilişki ya da pozitif ilişki bulan çalışmalar dışında bir ilişki bulamayan çalışmalar da mevcuttur. Çoğu çalışma bir ülkenin ekonomik gelişimine ve büyümesine sosyal sermayenin pozitif katkı yaptığı yönünde sonuçlar elde etmiştir. Putnam (1993), Knack and Keefer (1997), La Porta vd. (1997), Dasgupta and Sergaldin (2000), Glaeser vd. (2000), Zak and Knack (2001) ve Beugelsdijk ve Schaik (2004) bu çalışmalardan bazılardır. Ancak Helliwell (1996), Raiser vd. (2001), Roth (2007) gibi çalışmalarda ise sosyal sermaye ile ekonomik büyüme arasında negatif ilişki bulunmuştur. Bu konuyla ilgili literatür iki faklı tabloda özetlenmiştir.

Tablo: 2

Sosyal Sermaye ile Ekonomik Büyüme Arasında Pozitif İlişki Bulan Çalışmalar

\begin{tabular}{|l|c|c|c|c|l|}
\hline Yazarlar & Ülke/Bölge & Dönem & Yöntem & Değişkenler & Sonuç \\
\hline $\begin{array}{l}\text { Knack ve } \\
\text { Keefer (1997) }\end{array}$ & $\begin{array}{c}\text { 29 Piyasa } \\
\text { Ekonomisi }\end{array}$ & $1981-1991$ & EKK & $\begin{array}{c}\text { Sosyal Sermaye ve } \\
\text { Ekonomik } \\
\text { Performans Verileri }\end{array}$ & $\begin{array}{l}\text { Sosyal sermaye ve büyüme arasındaki } \\
\text { ilişkinin anlamlı ve güçlü olduğu yönündedir. }\end{array}$ \\
\hline $\begin{array}{l}\text { Hjerppe } \\
(1998)\end{array}$ & $\begin{array}{c}\text { Seçilmiş } 27 \\
\text { Ülke }\end{array}$ & $1990-1993$ & EKK & $\begin{array}{c}\text { Güven, Sivil } \\
\text { Örgülere Katılım ve } \\
\text { GSYİH }\end{array}$ & $\begin{array}{l}\text { Güven düzeyi ile büyüme arasında pozitif bir } \\
\text { ilişkinin olduğu sonucuna ulaş1lmıştır. }\end{array}$ \\
\hline $\begin{array}{l}\text { Temple and } \\
\text { Johnson } \\
(1998)\end{array}$ & $\begin{array}{c}74 \text { Gelişmekte } \\
\text { Olan Ülke }\end{array}$ & $1957-1962$ & EKK & $\begin{array}{l}\text { Sosyal Sermaye ve } \\
\text { Ekonomik Büyüme }\end{array}$ & $\begin{array}{l}\text { Ekonomik büyüme üzerinde sosyal } \\
\text { sermayenin önemli bir katk1 sağladığ1 sonucu } \\
\text { elde edilmiştir. }\end{array}$ \\
\hline $\begin{array}{l}\text { La Porta vd. } \\
(1999)\end{array}$ & $\begin{array}{c}\text { Seçilmiş 39 } \\
\text { Ülke }\end{array}$ & $1970-1993$ & $\begin{array}{c}\text { Güven (Kurumlar) } \\
\text { ve Ekonomik } \\
\text { Büyüme }\end{array}$ & $\begin{array}{l}\text { Güvenin, ekonomik büyümeyi hizlandırdığ1 } \\
\text { saptanmıştır. }\end{array}$ \\
\hline $\begin{array}{l}\text { Whiteley } \\
(2000)\end{array}$ & $\begin{array}{c}\text { Seçilmiş 34 } \\
\text { ülke. }\end{array}$ & $1970-1992$ & Zaman Serisi Analizi & $\begin{array}{c}\text { Bireyleraras1 Güven } \\
\text { ve Ekonomik } \\
\text { Büyüme }\end{array}$ & $\begin{array}{l}\text { Güvenin ekonomik büyüme üzerinde güçlü } \\
\text { bir etkiye sahip olduğu sonucuna ulaşmıştır. }\end{array}$ \\
\hline
\end{tabular}


Kızılkaya, O. (2017), “Sosyal Sermayenin Ekonomik Büyüme Üzerindeki Potansiyel Etkisi:

Türkiye İçin Yapısal Kırılmalı Eşbütünleșme Analizi”, Sosyoekonomi, Vol. 25(33), 175-194.

\begin{tabular}{|c|c|c|c|c|c|}
\hline $\begin{array}{l}\text { Zak ve Knack } \\
(2001)\end{array}$ & $\begin{array}{l}\text { Seçilmiş } 37 \\
\text { Ülke }\end{array}$ & 1970-1992 & EKK & $\begin{array}{l}\text { Güven Düzeyi ve } \\
\text { Ekonomik Büyüme }\end{array}$ & $\begin{array}{l}\text { Güven düzeyinin yüksek olduğu ülkelerde } \\
\text { daha yüksek büyüme oranlarının gerçekleştiği } \\
\text { sonucuna ulaşılmıştır. }\end{array}$ \\
\hline $\begin{array}{l}\text { Karagül ve } \\
\text { Akçay (2002) }\end{array}$ & $\begin{array}{l}\text { Seçilmiş } 36 \\
\text { Ülke }\end{array}$ & $\begin{array}{c}1960- \\
1995 / 1980- \\
1995\end{array}$ & Zaman Serisi Analizi. & $\begin{array}{l}\text { Sosyal Sermaye ve } \\
\text { Ekonomik Büyüme. }\end{array}$ & $\begin{array}{l}\text { Sosyal sermaye ve ekonomik büyüme } \\
\text { arasında önemli pozitif bir ilişki tespit } \\
\text { edilmiştir. }\end{array}$ \\
\hline $\begin{array}{l}\text { Baliamonue } \\
(2005)\end{array}$ & $\begin{array}{l}39 \text { Afrika } \\
\text { Ülkesi }\end{array}$ & $1975-2000$ & $\begin{array}{l}\text { Dengesiz Panel Veri } \\
\text { Analizi }\end{array}$ & $\begin{array}{l}\text { Sosyal Sermaye ve } \\
\text { Ekonomik Gelişme. }\end{array}$ & $\begin{array}{l}\text { Sosyal sermayenin gelir artışı üzerinde güçlü } \\
\text { bir etkisi olduğu sonucuna ulaşıllmıştır. }\end{array}$ \\
\hline $\begin{array}{l}\text { Perez vd. } \\
(2006)\end{array}$ & $\begin{array}{l}23 \text { OECD } \\
\text { ülkesi. }\end{array}$ & 1970-2001 & $\begin{array}{c}\text { GMM } \\
\text { (Genelleştirilmiş } \\
\text { Momentler Yöntemi) } \\
\text { Analizi }\end{array}$ & $\begin{array}{l}\text { Sosyal Sermaye ve } \\
\text { Ekonomik Büyüme. }\end{array}$ & $\begin{array}{l}\text { Sosyal sermaye ve ekonomik büyüme } \\
\text { arasında pozitif ilişkinin varlığı saptanmıştır. }\end{array}$ \\
\hline $\begin{array}{l}\text { Rupasingha } \\
\text { vd. (2006) }\end{array}$ & $\begin{array}{l}\text { ABD'nin baz1 } \\
\text { eyaletleri. }\end{array}$ & 1980-1997 & EKK & $\begin{array}{l}\text { Sosyal Sermaye ve } \\
\text { Ekonomik Büyüme }\end{array}$ & $\begin{array}{l}\text { Sosyal sermaye ile ekonomik büyüme } \\
\text { arasında pozitif bir ilişkinin olduğu sonucuna } \\
\text { ulaşılmıstır. }\end{array}$ \\
\hline $\begin{array}{l}\text { Dinçer ve } \\
\text { Uslaner } \\
(2007)\end{array}$ & $\begin{array}{l}\text { ABD'nin } 43 \\
\text { sinır komşusu } \\
\text { eyaleti. }\end{array}$ & $1990-2000$ & EKK & $\begin{array}{l}\text { Güven ve Ekonomik } \\
\text { Büyüme. }\end{array}$ & $\begin{array}{l}\text { Güven ve ekonomik büyüme arasında pozitif } \\
\text { bir ilişki tespit edilmiştir. }\end{array}$ \\
\hline $\begin{array}{l}\text { Berggren vd. } \\
(2008)\end{array}$ & $\begin{array}{l}\text { Seçilmiş } 63 \\
\text { Ülke }\end{array}$ & $\begin{array}{c}1970-1992 / \\
1990-2000\end{array}$ & EKK & $\begin{array}{l}\text { Güven ve Ekonomik } \\
\text { Büyüme }\end{array}$ & $\begin{array}{l}\text { Güven ve ekonomik büyüme arasında pozitif } \\
\text { ilişki tespit edilmiştir. }\end{array}$ \\
\hline Dinda (2007) & $\begin{array}{l}\text { Seçilmiş } 63 \\
\text { Ülke }\end{array}$ & $1990-2000$ & Zaman Serisi Analizi. & $\begin{array}{l}\text { Sosyal Sermaye, } \\
\text { Beşeri Sermaye ve } \\
\text { Ekonomik Büyüme. }\end{array}$ & $\begin{array}{l}\text { Sosyal sermayenin, ekonomik büyüme } \\
\text { üzerinde beşeri sermaye vasıtasıyla dolaylı } \\
\text { pozitif etkisinin olduğu tespit edilmiştir. }\end{array}$ \\
\hline $\begin{array}{l}\text { Akçomak ve } \\
\text { Weel (2008) }\end{array}$ & 14 AB ülkesi. & 1990-2002 & Üç Aşamalı EKK & $\begin{array}{l}\text { Sosyal Sermaye, } \\
\text { Yenilik ve Kişi } \\
\text { Başına Düşen Gelir } \\
\text { Artışı }\end{array}$ & $\begin{array}{l}\text { Sosyal sermayenin kişi başına gelir artışına } \\
\text { doğrudan bir katkı sağlamadığı fakat sosyal } \\
\text { sermayenin yenilik düzeyi vasıtasıyla kişi } \\
\text { başına düşen geliri artırdığı sonucuna } \\
\text { ulaşmışlardır. }\end{array}$ \\
\hline $\begin{array}{l}\text { Dearmon ve } \\
\text { Grier (2009) }\end{array}$ & $\begin{array}{l}\text { Seçilmiş } 51 \\
\text { ülke. }\end{array}$ & $\begin{array}{c}\text { 1981-2004 } \\
\text { dönemi } 4 \\
\text { periyod. }\end{array}$ & $\begin{array}{l}\text { Dengesiz Panel Veri } \\
\text { Analizi }\end{array}$ & $\begin{array}{l}\text { Güven ve Ekonomik } \\
\text { Büyüme. }\end{array}$ & $\begin{array}{l}\text { Güvenin ekonomik büyümeyi dolaylı olarak } \\
\text { etkilediği sonucuna ulaşılmıştır. }\end{array}$ \\
\hline $\begin{array}{l}\text { Okon, } \\
\text { Emmanuel vd } \\
(2013)\end{array}$ & Nijerya & 2012 & Logit Tahmin Modeli & $\begin{array}{c}\text { Sosyal Sermaye ve } \\
\text { Ekonomik Büyüme } \\
\text { (Kırsal alanda } \\
\text { yaşayan } 500 \\
\text { hanehalk1 verisi) }\end{array}$ & $\begin{array}{l}\text { Sosyal sermayenin kırsal alandaki ekonomik } \\
\text { büyüme üzerinde hızlandırıcı etkisinin olduğu } \\
\text { sonucuna ulaşılmışır }\end{array}$ \\
\hline $\begin{array}{l}\text { Feki ve } \\
\text { Chtouro } \\
(2014)\end{array}$ & $\begin{array}{l}\text { Gelişmiş ve } \\
\text { Gelişmekte } \\
\text { Olan Ülkeler }\end{array}$ & 1990-2004 & $\begin{array}{l}\text { Statik ve Dinamik } \\
\text { Panel Veri Analizi }\end{array}$ & $\begin{array}{l}\text { Sosyal Sermaye ve } \\
\text { Ekonomik Büyüme }\end{array}$ & $\begin{array}{l}\text { Yüksek güven düzeyi ile birlikte bireylerarası } \\
\text { iletişimin doğrudan ve dolaylı olarak } \\
\text { ekonomik büyüme üzerinde katkısı olduğunu } \\
\text { göstermektedir. }\end{array}$ \\
\hline $\begin{array}{l}\text { Aguilera } \\
\text { (2016) }\end{array}$ & $\begin{array}{c}\text { Güney ve } \\
\text { Kuzey ABD } \\
\text { ülkeleri. }\end{array}$ & 1994-2014 & Panel Veri Analizi & $\begin{array}{l}\text { Sosyal Sermaye ve } \\
\text { Ekonomik Büyüme }\end{array}$ & $\begin{array}{l}\text { Sosyal sermaye ile ekonomik büyüme } \\
\text { arasında pozitif bir ilişki bulunmuştur. }\end{array}$ \\
\hline
\end{tabular}

Tablo: 3

Sosyal Sermaye ile Ekonomik Büyüme Arasında Negatif İlişki Bulan / İlişki Bulamayan Çalışmalar

\begin{tabular}{|c|c|c|c|c|c|}
\hline Yazarlar & Ülke/Bölge & Dönem & Yöntem & Değişkenler & Sonuç \\
\hline $\begin{array}{l}\text { Helliwell } \\
(1996)\end{array}$ & Asya Ülkeleri & $\begin{array}{c}1987- \\
1994\end{array}$ & EKK & $\begin{array}{l}\text { Sosyal Sermaye, } \\
\text { Kurumsal Kalite ve } \\
\text { Ekonomik Büyüme. }\end{array}$ & $\begin{array}{l}\text { Sosyal sermaye ve kurumsal kalite ekonomik büyüme } \\
\text { üzerinde açılayıcı güce sahip değildir. }\end{array}$ \\
\hline $\begin{array}{l}\text { Raiser vd. } \\
(2001)\end{array}$ & $\begin{array}{l}\text { Sovyetler } \\
\text { Birliğinin Merkez } \\
\text { ve Doğu Geçiş } \\
\text { Ülkeleri. }\end{array}$ & $\begin{array}{l}1990- \\
1995\end{array}$ & EKK & $\begin{array}{l}\text { Sosyal Sermaye ve } \\
\text { Ekonomik Büyüme. }\end{array}$ & $\begin{array}{l}\text { Sosyal sermaye ile büyüme arasında pozitif bir ilişki } \\
\text { bulunamamıştır. }\end{array}$ \\
\hline Roth (2007) & Seçilmiş 41 ülke. & $\begin{array}{l}1990- \\
2004\end{array}$ & $\begin{array}{l}\text { Panel Veri } \\
\text { Analizi }\end{array}$ & $\begin{array}{l}\text { Sosyal Sermaye, } \\
\text { Güven ve } \\
\text { Ekonomik Büyüme. }\end{array}$ & $\begin{array}{l}\text { Güven ve ekonomik büyüme arasında negatif bir ilişki } \\
\text { gözlemlenmiştir. }\end{array}$ \\
\hline $\begin{array}{l}\text { Neira vd. } \\
(2010)\end{array}$ & $\begin{array}{l}\text { AB-15 ülkeleri ve } \\
\text { AB'nin Doğu } \\
\text { Ülkeleri. }\end{array}$ & $\begin{array}{l}2002- \\
2008\end{array}$ & $\begin{array}{l}\text { Yatay Kesit } \\
\text { Analizi }\end{array}$ & $\begin{array}{l}\text { Sosyal Sermaye, } \\
\text { Beşeri Sermaye ve } \\
\text { Ekonomik Büyüme. }\end{array}$ & $\begin{array}{l}\text { Sosyal sermaye ile ekonomik büyüme arasında kesin bir } \\
\text { ilişki tespit edilememiştir. }\end{array}$ \\
\hline $\begin{array}{l}\text { Iyer vd. } \\
(2005)\end{array}$ & ABD'de 9 bölge. & 2000 & $\begin{array}{l}\text { Siralı Logit } \\
\text { Regresyon } \\
\text { Modeli }\end{array}$ & $\begin{array}{l}\text { Sosyal Sermaye, } \\
\text { Bölgesel Kalkınma } \\
\text { ve Ekonomik } \\
\text { Büyüme. }\end{array}$ & $\begin{array}{l}\text { Kalkınma ile sosyal sermaye arasında pozitif ilişkinin } \\
\text { varlığını tespit edilirken sosyal sermaye ile ekonomik } \\
\text { büyüme arasındaki ilişki için güçlü deliller } \\
\text { bulunamamıştır. }\end{array}$ \\
\hline $\begin{array}{l}\text { Neira vd } \\
(2008)\end{array}$ & $\begin{array}{l}14 \text { Gelişmiş } \\
\text { OECD ülkesi. }\end{array}$ & $\begin{array}{l}1980- \\
2000\end{array}$ & $\begin{array}{c}\text { Panel Veri } \\
\text { Analizi }\end{array}$ & $\begin{array}{l}\text { Sosyal Sermaye, } \\
\text { Beșeri Sermaye ve } \\
\text { Ekonomik Büyüme. }\end{array}$ & $\begin{array}{l}\text { Sosyal sermayenin ekonomik büyüme için çok önemli } \\
\text { olduğuna sonucuna ulaşılırken sosyal sermayenin tek } \\
\text { başına ekonomik gelişmeyi hızlandıramayacağı } \\
\text { belirtilmiştir. }\end{array}$ \\
\hline
\end{tabular}


Kızılkaya, O. (2017), “Sosyal Sermayenin Ekonomik Büyüme Üzerindeki Potansiyel Etkisi:

Türkiye İçin Yapısal Kırılmalı Eşbütünleşme Analizi”, Sosyoekonomi, Vol. 25(33), 175-194.

\begin{tabular}{|c|c|c|c|c|c|}
\hline Pfister (2010) & Seçilmiş 116 ülke. & $\begin{array}{l}1950- \\
2005\end{array}$ & $\begin{array}{l}\text { Panel Veri } \\
\text { Analizi }\end{array}$ & $\begin{array}{l}\text { Sosyal Güven ve } \\
\text { Ekonomik Büyüme. }\end{array}$ & $\begin{array}{l}\text { Sosyal güvenin ekonomik büyüme üzerindeki etkisinin } \\
\text { ülkenin gelişmişlik seviyesine göre değişeceği sonucuna } \\
\text { ulaşıllmıştır. }\end{array}$ \\
\hline $\begin{array}{l}\text { Hall ve } \\
\text { Ahmad (2013) }\end{array}$ & $\begin{array}{l}\text { Gelişmekte olan } \\
69 \text { ülke. }\end{array}$ & $\begin{array}{l}1984- \\
2008\end{array}$ & $\begin{array}{l}\text { Panel Veri } \\
\text { Analizi }\end{array}$ & $\begin{array}{l}\text { Güven, Mülkiyet } \\
\text { Hakları ve } \\
\text { Ekonomik Büyüme }\end{array}$ & $\begin{array}{l}\text { Dünya değerler anketinden alınan verilerde eksikler olması } \\
\text { sebebiyle çalışmada elde edilen sonuçların çok sağlıklı } \\
\text { olmadığı ifade edilmiştir. }\end{array}$ \\
\hline $\begin{array}{l}\text { Salahuddin, } \\
\text { Tisdell vd } \\
\text { (2015) }\end{array}$ & Avustrulya & $\begin{array}{l}1985- \\
2013\end{array}$ & $\begin{array}{l}\text { Zaman Serisi } \\
\quad \text { Analizi }\end{array}$ & $\begin{array}{l}\text { Sosyal Sermaye, } \\
\text { İternet Kullanımı } \\
\text { ve Ekonomik } \\
\text { Büyüme. }\end{array}$ & $\begin{array}{l}\text { İnternet kullanımı ve ekonomik büyüme arasında uzun } \\
\text { dönemde anlamlı bir ilisski tespit edilirken sosyal sermaye } \\
\text { ve ekonomik büyüme arasında ne kısa ne de uzun } \\
\text { dönemde önemli bir ilişski tespit edilememiştir. }\end{array}$ \\
\hline $\begin{array}{l}\text { Sabatini } \\
(2006)\end{array}$ & İtalya & $\begin{array}{l}1998- \\
2002\end{array}$ & $\begin{array}{l}\text { Zaman Serisi } \\
\text { Analizi }\end{array}$ & $\begin{array}{l}\text { Sosyal Sermaye ve } \\
\text { Ekonomik Gelişme. }\end{array}$ & $\begin{array}{l}\text { Sosyal sermaye çeşitliliğinin ve sosyal sermayeyi oluşturan } \\
\text { etkenlerin ekonomik gelişme üzerinde pozitif bir etkisinin } \\
\text { bulunmadığı, aksine bireyler arası zayıf bağların doğrudan } \\
\text { veya dolaylı olarak ekonomik gelişmeye katkı } \\
\text { sağlayabileceği sonucuna ulaşılıștır. }\end{array}$ \\
\hline $\begin{array}{l}\text { Palamino } \\
(2016)\end{array}$ & $\begin{array}{l}\text { Avrupa'daki } 237 \\
\text { bölge }\end{array}$ & $\begin{array}{l}1995- \\
2007\end{array}$ & $\begin{array}{l}\text { Parametrik } \\
\text { Olmayan } \\
\text { Regresyon } \\
\text { Modeli }\end{array}$ & $\begin{array}{l}\text { Sosyal Sermaye ve } \\
\text { Ekonomik Büyüme }\end{array}$ & $\begin{array}{l}\text { Sosyal sermaye ve ekonomik büyüme ilişkisinin doğrusal } \\
\text { olmadığı sonucuna ulaşılmıştır. }\end{array}$ \\
\hline
\end{tabular}

\section{Ampirik Uygulama}

\subsection{Türkiye İçin Sosyal Sermaye Endeksinin Hesaplanması}

Bu çalışmada sosyal sermaye endeksi sekiz temel gösterge kullanılarak TBA yöntemi ile hesaplanacaktır. TBA, aralarında ilişki bulunan çok sayıda değişkenin açıklayabildiği bir ilişkiyi, mevcut değişkenlerin özelliklerinin önemli bir kısmını içeren tek bir endeks ile açıklamaya olanak sağlayan bir analiz yöntemidir. Bu yöntem ile birden fazla iktisadi gösterge tek bir göstergede toplanabilmektedir.

TBA için ilgili göstergelere ait veriler Uluslararası Ülke Risk Rehberi (ICRG)'nden elde edilmiştir. Sosyal sermaye endeksini temsil edecek temel göstergeler: Sözleşme uygulanabilirliği (KONT), kanun ve düzen (LO), ekonomik risk değerlendirmesi (ER), finansal risk değerlendirmesi (FR), politik risk değerlendirmesi (PR), demokratik hesap verilebilirlik (DEM), hükümet istikrarına (GOV) ve yasama gücüne (LEG) ait reytinglerdir. Tablo 4'de göstergelere ait korelasyon ilişkisi gösterilmektedir.

Tablo: 4

Göstergelere Ait Korelasyon İlişkisi

\begin{tabular}{|l|c|c|c|c|c|c|c|c|}
\hline & KONT & LO & ER & FR & PR & DEM & GOV & LEG \\
\hline KONT & 1 & & & & & & & \\
\hline LO & 0,67 & 1 & & & & & & \\
\hline ER & 0,09 & $-0,22$ & 1 & & & & & \\
\hline FR & $-0,30$ & $-0,52$ & $-0,04$ & 1 & & & & \\
\hline PR & 0,89 & 0,81 & $-0,12$ & $-0,31$ & 1 & & & \\
\hline DEM & 0,72 & 0,90 & $-0,21$ & $-0,30$ & 0,88 & 1 & & \\
\hline GOV & 0,78 & 0,57 & $-0,05$ & $-0,12$ & 0,87 & 0,76 & 1 & \\
\hline LEG & 0,69 & 0,63 & 0,02 & $-0,27$ & 0,85 & 0,75 & 0,90 & 1 \\
\hline
\end{tabular}

TBA analizine geçmeden önce ilgili göstergeler bir araya getirilebilir şekilde standardizasyon yöntemi ile dönüştürmeye tabi tutulmuştur. Böylece her bir gösterge ait birim değerleri arasındaki farklılık ortadan kalkmaktadır. Sonrasında ise, TBA analizi için verilerin uygunluğu Kaiser-Meyer-Olkin (KMO) ve Bartlett testi ile değerlendirilmiştir. Test sonuçları değişkenler arasında bir ilişkinin varlığı desteklemekte olup; endeks oluşturmada bir sakınca olmadığı ortaya koymuştur. 
TBA için değişkenler arasındaki maksimum varyansı açıklayan faktörler hesaplanmış ve hesaplanan faktörlerden özdeğeri 1'den büyük ve açıklama oranı en yüksek bileşen dikkate alınmıştır. TBA sonuçları Tablo 5'de raporlanmıştır. TBA sonuçlarına göre, ilk temel bileşenin özdeğeri 1'den büyük ve toplam varyansı açıklama oranı $\% 63$ olup diğer bileşenlere göre daha başarılıdır. Ayrıca ilk bileşende, sosyal sermaye endeksini oluşturacak olan göstergelerin ağırlıkları iktisadi beklentiye uygun çıkmıştır.

Tablo: 5

Temel Bileșenler Analiz Sonucu

\begin{tabular}{|c|c|c|c|c|c|}
\hline & TBA 1 & TBA 2 & TBA 3 & TBA 4 & TBA5 \\
\hline Özdeğerler & 5,08 & 1,09 & 1,01 & 0,34 & 0,29 \\
\hline Varyans Yüzdesi & 0,63 & 0,13 & 0,12 & 0,04 & 0,03 \\
\hline Kümülatif Yüzde & 0,63 & 0,76 & 0,88 & 0,92 & 0,95 \\
\hline Değişkenler & Vektör 1 & Vektör 2 & Vektör 3 & Vektör 4 & Vektör 5 \\
\hline KONT & 0,38 & 0,16 & 0,01 & 0,53 & $-0,51$ \\
\hline LO & 0,38 & $-0,29$ & $-0,17$ & 0,31 & 0,47 \\
\hline ER & $-0,05$ & 0,81 & $-0,47$ & 0,17 & 0,27 \\
\hline FR & $-0,18$ & 0,28 & 0,80 & 0,32 & 0,33 \\
\hline PR & $-0,33$ & 0,05 & 0,09 & 0,13 & $-0,09$ \\
\hline DEM & 0,41 & $-0,15$ & 0,04 & 0,10 & 0,43 \\
\hline GOV & 0,39 & 0,24 & 0,28 & $-0,31$ & $-0,15$ \\
\hline LEG & 0,39 & 0,24 & 0,09 & $-0,50$ & 0,11 \\
\hline \multicolumn{6}{|c|}{ Örnekleme yeterliliği ölçümü } \\
\hline Kaiser-Meyer-Olkin & & 0,72 & & & \\
\hline Bartlett ki-kare & & 83,17 & & & \\
\hline Bartlett olasilik & & 0,00 & & & \\
\hline
\end{tabular}

\subsection{Model ve Veri Seti}

Bu çalışmada Türkiye'de sosyal sermayenin ekonomik büyüme üzerindeki etkisi 2006-2014 çeyrek dönem verileri ile geleneksel üretim fonksiyonu yardımıyla araştırılacaktır. Araştırma için tahmin edilecek model şöyledir:

$$
\ln \mathrm{Y}_{\mathrm{t}}=\beta_{0}+\beta_{1} \ln \mathrm{K}_{\mathrm{t}}+\beta_{2} \ln \mathrm{L}_{\mathrm{t}}+\beta_{3} \mathrm{SS}+\varepsilon_{\mathrm{t}}
$$

(1) numaralı denklemde $\ln Y$ reel GSYİH (1998 yılı fiyatlarıyla milyon TL), $\ln K$ gayri safi sabit sermaye oluşumunu (1998 yılı fiyatlarıyla milyon TL), lnL işgücüne katılım oranını (\%)) ve $\ln S$ sosyal sermaye endeksini temsil etmektedir. Analizde kullanılan $\ln Y$, $\ln K$ ve $\ln L$ 'ye ait seriler mevsimsel etkilerden arındırılırmış olup, daha etkin tahmincilere ulaşmak için doğal logaritmaları alınmıştır. Reel GSYİH, gayri safi sabit sermaye oluşumunu ve işgücüne katılım oranına ait veriler T.C. Merkez Bankasından elde edilmiştir. $S S$ ise TBA yöntemi ile hesaplanan sosyal sermaye endeksini göstermektedir. Grafik 1'de analizde kullanılan serilerin eğilimleri gösterilmektedir.

(1) numaralı denklemde t zaman periyodunu, $\varepsilon$ hata terimini, $\beta_{0}$ sabiti ve $\beta_{1}, \beta_{2}, \beta_{3}$ ise sırasıyla sermayenin, işgücünün ve sosyal sermayenin reel gelirdeki büyüme üzerindeki etkisini ortaya koyan esneklik katsayılarını göstermektedir. İktisadi olarak tahmin edilecek olan katsayıların işaretinin pozitif ve anlamlı olması beklenmektedir. 


\section{Grafik: 1}

\section{Analizde Kullanılan Serilerin Eğilimleri (2006Ç1-2014Ç4)}

$\ln Y$ $\operatorname{lnK}$
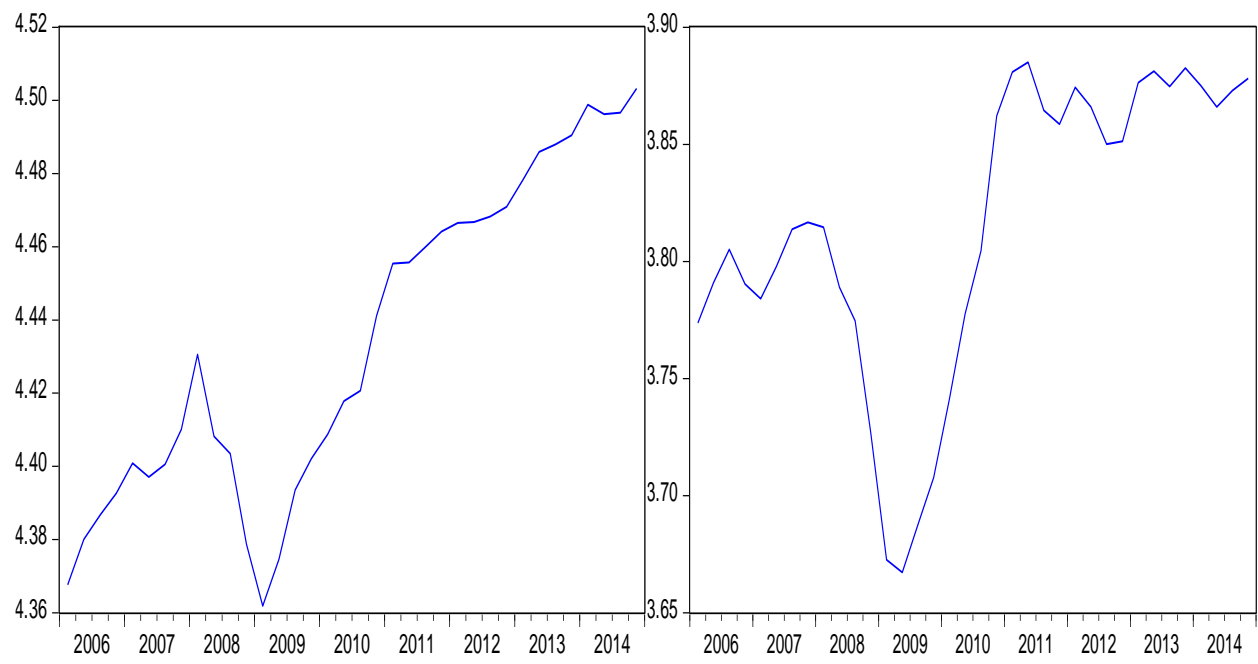

$\operatorname{lnL}$

SS

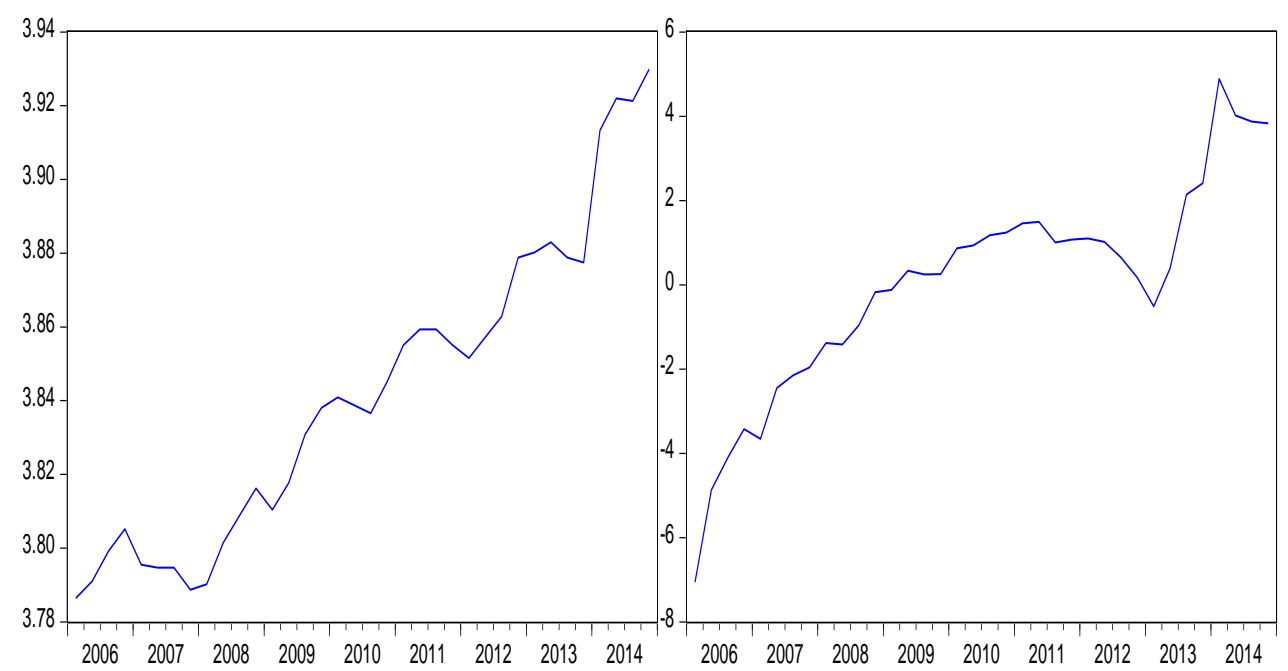

\subsection{Ekonometrik Yöntem}

Çalışmada ekonometrik analiz için öncelikle değişkenlere ait serilerin durağanlıkları sınanacaktır. Çünkü durağan olmayan seriler ile yapılan tahminlerde sahte regresyon sorunu 
ortaya çıkmaktadır (Granger \& Newbold, 1974: 111). Bunun için Dickey ve Fuller (1981) ve Phillips ve Perron (1988) tarafindan geliştirilen geleneksel birim kök testleri sıklıkla kullanılmaktadır. Birim kök testleri sonucunda genellikle serilerin düzey değerlerinde durağan olmadığını ancak ilk farklarında durağan olduğunu gözlemlenmektedir. Bu durumda değişkenler arasındaki ilişkilerin tahmin edilebilmesi için eşbütünleşme analizleri gerekmektedir. Eşbütünleşme ilişkisinin varlığı durumunda sahte regresyon sorunu oradan kalkmakta ve uzun dönem katsayıları tahmin edilebilmektedir.

Eşbütünleşme analizi için Engle ve Granger (1987), Johansen (1988), Johansen ve Juselius (1990) ve Pesaran vd. (2001) tarafından geliştirilen eşbütünleşme yöntemleri sıklıkla kullanılmaktadır. Ancak bu geleneksel eşbütünleşme yöntemleri yapısal kırılmaları dikkate almamaktadır. Ancak bir ülkede belirli bir dönem aralığında krizler, teknolojik gelişmeler, siyasi bunalımlar, askeri meseleler gibi ekonominin yapısını etkileyecek değişiklikler/kırılmalar ortaya çıkabilmektedir. İşte geleneksel eşbütünleşme yöntemlerinin bu değişiklikleri/kırılmaları dikkate almaması bu yöntemlerle ilgili önemli bir kısıt oluşturmaktadır. Bu nedenle bu çalışmada Maki (2012) tarafından geliştirilen ve beş yapısal kırılmaya kadar tahmin edebilen eşbütünleşme yöntemi kullanılacaktır.

Maki (2012) eşbütüleşme testine göre örnekleme sürecinde her dönem için olası bir kırılma noktası ve $\mathrm{t}$ istatistikleri hesaplanır. Sonra en düşük t istatistikleri kırılma noktaları olarak belirlenir. Maki (2012) birden fazla kırılma noktası varsayımı altında eşbütünleşme ilişkisini test etmek için aşağıdaki modelleri geliştirmiştir:

$$
\begin{aligned}
& y_{t}=\mu+\sum_{i=1}^{k} \mu_{i} D_{i, t}+\beta^{\prime} x_{t}+\mu_{t} \\
& y_{t}=\mu+\sum_{i=1}^{k} \mu_{i} D_{i, t}+\beta^{\prime} x_{t}+\sum_{i=1}^{k} \beta_{i}^{\prime} x_{t} D_{i, t}+\mu_{t} \\
& y_{t}=\mu+\sum_{i=1}^{k} \mu_{i} D_{i, t}+\gamma t+\beta^{\prime} x_{t}+\sum_{i=1}^{k} \beta_{i}^{\prime} x_{t} D_{i, t}+\mu_{t} \\
& y_{t}=\mu+\sum_{i=1}^{k} \mu_{i} D_{i, t}+\gamma t+\sum_{i=1}^{k} \gamma_{i} t D_{i, t}+\beta_{i}^{\prime} x_{t}+\sum_{i=1}^{k} \beta_{i}^{\prime} x_{t} D_{i, t}+u_{t}
\end{aligned}
$$

(2-5) numaralı denklemlerde $\mathrm{t}=1,2, \ldots . \mathrm{T} . y_{t}$ ve $x_{t}=\left(x_{t}, \ldots, x_{m t}\right)^{\prime} \mathrm{I}(1)^{\prime} \mathrm{de}$ gözlemlenebilir değişkenleri ve $u_{t}$ hata terimlerini temsil etmektedir. 2 nolu denklem trendsiz modelde sabit terimde kırılmayı, 3 nolu denklem trendsiz modelde sabit terim ve eğim kırılmasını, 4 nolu denklem trendle genişletilmiş ve trendli modelde sabit terim ve eğim kırılmasını, 5 nolu denklem ise sabit terim, eğim ve trend kırılmasını ifade eder. Maki (2012) kritik değerler Monte Carlo simulasyonu ile belirlenmiş ve Maki (2012)'de verilmiştir. Hesaplanan test istatistiklerinin kritik değerlerden küçük olması durumunda seriler arasında eşbütünleşme ilişkisinin olmadığını söyleyen boş hipotez reddedilmektedir.

Eşbütünleşme ilişkisinin belirlenmesinden sonra uzun dönem katsayılarının tespiti için Stock-Watson(1993) tarafından geliştirilen Dinamik En Küçük Kareler Yöntemi (Dynamic Ordinary Least Squares - DOLS) tercih edilmiştir. Bu yöntem küçük örneklerde kullanılabilen, bağımsız değişkenlerin farklarının gecikmeli değerlerini içermektedir. Ayrıca DOLS yöntemi bağımsız değişkenlerdeki içsellik ve otokorelasyonun varlığı 
durumunda güçlü (robust) tahminler üretebilmesi avantajlarından dolayı çalışmada tercih edilmiştir.

\subsection{Analiz Bulguları}

Tablo 6'da birim kök test sonuçları raporlanmıştır. Test sonuçlarına göre analiz için kullanılan serilerin tamamı düzey değerlerinde durağan değildir. Bu nedenle seriler ilk farkları alınıp tekrar birim kök araştırmasına devam edilmiştir. İlk fark sonuçlarına göre ise serilerin tamamı durağan çıkmıştır. Bu durumda değişkenler arasında uzun dönemli bir eşbütünleşme ilişkisinin varlığını araştırmak gerekmektedir.

Tablo: 6

Birim Kök Test Sonuçları

\begin{tabular}{|c|c|c|}
\hline Değişkenler & ADF testi & PP testi \\
\hline $\ln \mathrm{Y}$ & $-0,57$ & $-0,58$ \\
\hline $\ln K$ & $-1,89$ & $-1,39$ \\
\hline $\operatorname{lnL}$ & 0,66 & 1,79 \\
\hline SS & $-1,62$ & $-1,77$ \\
\hline$\Delta \ln Y$ & $-4,36^{\mathrm{a}}$ & $-4,33^{\mathrm{a}}$ \\
\hline$\Delta \operatorname{lnK}$ & $-2,98^{b}$ & $-2,96^{b}$ \\
\hline$\Delta \ln \mathrm{L}$ & $-5,03^{\mathrm{a}}$ & $-5,07^{\mathrm{a}}$ \\
\hline$\Delta \mathrm{SS}$ & $-6,14^{\mathrm{a}}$ & $-6,17^{\mathrm{a}}$ \\
\hline \multicolumn{3}{|c|}{ Kritik Değerler } \\
\hline$\% 1$ & $-3,63$ & $-3,63$ \\
\hline$\% 5$ & $-2,95$ & $-2,94$ \\
\hline$\% 10$ & $-2,61$ & $-2,61$ \\
\hline
\end{tabular}

a, \%1 önem düzeyinde istatistiki anlamlılı̆̆l göstermektedir.

${ }^{b}$, \%5 önem düzeyinde istatistiki anlamlıliğl göstermektedir.

Tablo 7'de Maki (2012) eşbütünleşme test sonuçları sunulmuştur. Test sonuçlarına göre 4 modelde eşbütünleşme yoktur şeklindeki boş hipotezi reddetmektedir. Buna göre uzun dönemde reel gelir, sermaye, işgücüne katılım oranı ve sosyal sermaye beraber hareket etmektedir. $\mathrm{Bu}$ nedenle sonraki aşamada değişkenler arasındaki ilişkileri ortaya koyan katsayılarının tahminine geçilecektir.

Tablo 7'de Maki (2012) test sonuçları ayrıca Türkiye ekonomisi için kırılma tarihlerini göstermektedir. Örneğin; 2007ç4, 2008ç2, 2008ç3, 2009ç1, 2009ç3 ve 2009ç4 dönemleri 2007 yılının ortalarında ABD'de başlayan, 2008 yılının ikinci yarısında hızlanarak birçok ülkeyi etkisine alan ve 2009 yılında ise Türkiye'de etkisini gösteren küresel finansal krizi işaret etmektedir. Ayrıca 2007-2009 yılları arasında Türkiye'nin AB sürecinin yavaşladığı ile ilgili ve reformların devamı konusunda tartışmaların artığı bir dönemdir. 2010-2014 yılları ise dış kaynaklı krizden dolayı Türkiye'nin mali disiplinin uyguladığı ve para politikaları ile yapısal reformlarla krizin etkisini hafifletmeye çalıştığı bir dönem olmuştur. Fakat 2010 yılında bazı Avrupa Birliği ülkelerinde ortaya çıkan Avrupa Borç Krizi ekonomiyi olumsuz etkilemiştir. İç ve diş talebi dengelemeye yönelik alınan tedbirler sonucu Türkiye ekonomisinde 2012 yılı ve 2013 yılı ilk üç çeyrekte büyüme hızının yavaşladığ 1 dönemler olmuştur. 
Tablo: 7

Eşbütünleşme Test Sonuçları

\begin{tabular}{|c|c|c|c|c|c|}
\hline \multirow{2}{*}{ Model } & \multirow{2}{*}{ Test İst. } & \multicolumn{3}{|c|}{ Kritik Değerler $^{\mathrm{a}}$} & \multirow{2}{*}{ Kırılma Tarihleri } \\
\hline & & $\% 1$ & $\% 5$ & $\% 10$ & \\
\hline 0 & $-5,87^{\mathrm{c}}$ & $-6,55$ & $-6,03$ & $-5,77$ & $\begin{array}{c}2007 \_4,2009 \_3,2010 \_1, \\
2010 \_4,2013 \_3\end{array}$ \\
\hline 1 & $-11,42^{\mathrm{b}}$ & $-6,78$ & $-6,25$ & $-5,97$ & $\begin{array}{c}2008 \_2,2009 \_1,2009 \_4, \\
2013 \_2,2014 \_2\end{array}$ \\
\hline 2 & $-13,87^{b}$ & $-8,67$ & $-8,11$ & $-7,79$ & $\begin{array}{c}2007 \_4,2009 \_4,2010 \_4, \\
2012 \_1,2013 \_1\end{array}$ \\
\hline 3 & $-11,69^{b}$ & $-9,42$ & $-8,80$ & $-8,50$ & $\begin{array}{c}2007 \_2,2008 \_3,2009 \_4, \\
2011 \_1,2013 \_1\end{array}$ \\
\hline
\end{tabular}

${ }^{a}$, kritik değerler Maki(2012) tablo 1'den elde edilmiştir.

${ }^{b}, \% 1$ önem düzeyinde istatistiki anlamlıliğl göstermektedir.

c, \%10 önem düzeyinde istatistiki anlamlılığl göstermektedir.

Ampirik araştırmanın son aşamasında, değiş̧kenler arasındaki ilişkiye ait katsayılarının tahmini için DOLS yöntemi kullanılmıştır. Tahmin için öncelikle Maki (2012) test sonucu elde edilen ve Model 0'a ait olan kırlma tarihleri modele kukla (dummy) değişkenler olarak ilave edilmiştir. Böylece ilgili tarihlerde yaşanan gelişmelerin/şokların reel gelir üzerindeki etkisi ortaya konulabilecektir. Tablo 8'de tahmin sonuçları gösterilmektedir.

Tablo: 8

Katsayı Tahmin Sonuçları

\begin{tabular}{|c|c|c|c|}
\hline \multicolumn{4}{|l|}{ Bağımlı Değişken: $\ln Y$} \\
\hline Açıklayıcı Değişkenler & Katsay1 & $\mathrm{t}$ istatistiğ $\mathrm{i}$ & p-olasılık değeri \\
\hline $\ln K$ & $0,485^{\mathrm{a}}$ & \begin{tabular}{|l|l|}
8,819 \\
\end{tabular} & 0,000 \\
\hline $\operatorname{lnL}$ & $0,212^{\mathrm{b}}$ & 1,835 & \begin{tabular}{|l|l|}
0,077 \\
\end{tabular} \\
\hline SS & $\mid 0,057^{\mathrm{a}}$ & 2,874 & 0,006 \\
\hline dummy1 & $-0,005^{\mathrm{a}}$ & $-2,785$ & 0,009 \\
\hline dummy2 & $-0,067^{\mathrm{a}}$ & $-4,343$ & 0,000 \\
\hline dummy3 & $-0,015$ & $-1,025$ & 0,312 \\
\hline dummy4 & $-0,024$ & $-1,556$ & 0,115 \\
\hline dummy5 & 0,037 & 0,384 & 0,739 \\
\hline Sabit & $1,763^{\mathrm{a}}$ & 3,911 & \begin{tabular}{|l|l|}
0,000 \\
\end{tabular} \\
\hline
\end{tabular}

a, \%1 önem düzeyinde istatistiki anlamlılı̆̆ göstermektedir.

b, \%10 önem düzeyinde istatistiki anlamlılığl göstermektedir.

Tahmin sonuçlarına göre;

- $\quad$ lnK değişkenine ait katsayı 0,485 olup, \%1 önem düzeyinde anlamlıdır. Bu durum Türkiye'de araştırma yapılan dönemler arasında sabit sermaye düzeyindeki artı̧ıı reel gelir üzerinde pozitif bir etkiye neden olduğunu ortaya koymaktadır.

- lnL değişkenine ait katsayı 0,212 olup, \%10 önem düzeyinde anlamlıdır. Buna göre Türkiye'de işgücüne katılım oranındaki artış reel gelir üzerinde pozitif bir etkiye neden olmaktadır.

- SS değişkenine ait katsayı 0,057 olup, \%1 önem düzeyinde anlamlıdır. Bu durum Türkiye'de sosyal sermaye düzeyindeki bir artışın reel gelir üzerinde pozitif bir 
Kızılkaya, O. (2017), "Sosyal Sermayenin Ekonomik Büyüme Üzerindeki Potansiyel Etkisi:

Türkiye İçin Yapısal Kırılmalı Eşbütünleşme Analizi”, Sosyoekonomi, Vol. 25(33), 175-194.

etkiye neden olduğunu göstermektedir. Diğer bir ifadeyle sosyal sermaye düzeyinin ekonomik büyüme/reel gelir artışında anlamlı bir etkisi bulunmaktadır. $\mathrm{Bu}$ sonuç literatürde sosyal sermayenin ekonomik büyüme/gelir üzerinde pozitif bir etkisi olduğunu ifade eden çalışmalar ile uyumludur.

- Türkiye'deki kırılma tarihlerini temsil eden kukla değişkenlerden dummy1 (2007ç4) ve dummy2 (2009ç3)'nin katsayıları negatif ve istatistiki olarak anlamlıdır. Bu sonuçlar ABD'de ortaya çıkan küresel finans krizinin reel gelir artışını olumsuz yönde etkilediğini göstermektedir.

\section{Sonuç}

Bu çalışma Türkiye'de sosyal sermayenin ekonomik büyüme üzerindeki etkisini 2006-2014 çeyrek dönem verileri ile geleneksel üretim fonksiyonu kapsamında araştırmıştır. Araştırma için öncelikle TBA yöntemi ile sosyal sermaye endeksi hesaplanmıştır. Sonraki aşamada sosyal sermaye endeksi, işgücüne katılım oranı ve sabit sermayenin reel gelir üzerindeki etkisi Maki (2012) yapısal kırılmalı eşbütünleşme testi ve Stock-Watson (1993) DOLS tahmin yöntemi ile incelenmiştir. Eşbütünleşme test sonuçları değişkenler arasındaki uzun dönemli ilişkiyi desteklemiştir. DOLS tahmin sonuçları ise Türkiye'de sosyal sermayenin reel gelir üzerinde pozitif ve anlamlı bir etkisi olduğunu ortaya koymuştur. Çalışmadaki bulgular literatürdeki Putnam vd. (1993), Knack \& Keefer (1997), La Porta vd. (1997), Hjerppe (1998), Temple \& Johnson (1998), Dasgupta \& Sergaldin (2000), Glaeser vd. (2000), Zak \& Knack (2001), Annen (2001), Karagül \& Akçay (2002), Routledge \& Amsberg (2003), Beugelsdijk \& Schaik (2004), Casey (2004), Dinçer \& Uslaner (2007), Feki \& Chtouro (2014), Ponzetto \& Troiano (2014), Aguilera (2016) gibi çalışmalar tarafından desteklenmektedir.

$\mathrm{Bu}$ sonuçlar değerlendirildiğinde, bir ülkenin ekonomi politikaları çerçevesinde büyümenin kaynakları olarak sermaye, işgücü, doğal kaynaklar ve teknoloji ile beraber sosyal sermaye gibi faktörleri de dikkate alması gerektiği ortaya çıkmaktadır. Özellikle, ekonomide güven faktörünün sağlanması piyasadaki belirsizliği azaltmaktadır. Kişiler ve gruplar arasında uyumun, iletişimin ve güvene dayalı ilişkilerin gelişmesi kurumlar arasındaki ilişkileri kuvvetlendirmekte ve ekonomik verimliliği artırmaktadır. Ekonomik verimliliğin artması ise üretimin artmasına katkı sağlamaktadır. Türkiye'nin ekonomik gelişim sürecinde bunu yapabilmesi için çalışmanın kapsamına bağlı olarak temel öneriler şu şekilde sıralanabilir: i) Bireyler ve kurumlararası iletişimi arttıracak, güveni güçlendirecek reformlar geliştirerek sosyal sermaye düzeyinin artırılması. ii) Demokrasi ve demokrasinin uygulanabilirliği, demokrasiye katılım ve yönetim biçimleri, hukukun üstünlüğ̈̈ ve yargı bağımsızlığı gibi değerlerden taviz verilmemesi ve bu değerlerin kurumların gelişim sürecine katkı yapacak düzeye getirilmesi. iii) Sosyal uyum ve sivil uzlaşı sağlanarak demokrasinin güçlendirilmesi. iv) Kamu yönetimindeki etkinliğin ve liyakatın geliştirilmesi. v) İş yapma maliyetlerinin ve bürokrasinin azaltılarak kamuda görevi kötüye kullanılmasının engellenmesi. vi) Hükümetlerin ulusal ölçekte toplumsal iletişim ve güveni geliştirecek, uluslararası alanda ise ülkenin kredibilitesini artıracak uygulamaları ekonomi politikaları kapsamında dikkate alması. Yukarıda belirtilen yaklaşımlar ile uygulanacak politika ve reformlar ekonomik büyüme için çok önemli teşvikler sunacaktır. 


\section{Kaynaklar}

Aguilera, J.C. (2016), Social Capital and Economic Growth, LUND University, School of Economics and Management, <http://lup.lub.lu.se/luur/download?func=downloadFile\&recordOId=8618986\&fileOId= 8618987>, 15.01.2016.

Akçay, S. (2005), "Sosyal Sermaye ve Kalkınma”, M. Kar \& S. Taban (eds.), İktisadi Kalkınmada Sosyal, Kültürel ve Siyasal Faktörlerin Rolü”, Ekin Kitabevi, Bursa, 199-220.

Akçomak, I.S. \& B. Ter Weel (2009), "Social capital, innovation and growth: Evidence from Europe", European Economic Review, 53(5), 544-567.

Almond, G.A. \& V. Sidney (1963), The Civic Culture: Political Attitudes and Democracy in Five Nations, Newbury Park, Calif.: Sage.

Annen, K. (2003), "Social Capital, Inclusive Networks and Economic Performance”, Journal of Economic Behavior \& Organization, 50(4), 449-463.

Baker, W.E. (1990), “Market Networks and Corporate Behavior”, American Journal of Sociology, 96(3), 589-625.

Baliamoune-Lutz, M. (2005), "Institutions, Social Capital, and Economic Development in Africa: An Empirical Study", International Centre for Economic Research Working Paper Series, (18), 2007-05.

Berggren, N. \& M. Elinder \& H. Jordahl (2008), “Trust and Growth: A Shaky Relationship", Empirical Economics, 35(2), 251-274.

Beugelsdijk, S. \& T. Van Schaik (2005), "Social Capital and Growth in European Regions: An Empirical Test", European Journal of Political Economy, 21(2), 301-324.

Bjørnskov, C. (2003), "The Happy Few: Cross-Country Evidence on Social Capital and Life Satisfaction”, Kyklos, 56(1), 3-16.

Bourdieu, P. \& L.J. Wacquant (1992), An Invitation To Reflexive Sociology, University of Chicago Press.

Casey, T. (2004), “Social Capital and Regional Economies in Britain”, Political Studies, 52(1), 96117.

Casey, T. \& K. Christ (2005), "Social Capital and Economic Performance in the American States", Social Science Quarterly, 86(4), 826-845.

Coleman, J.S. (1988), "Social Capital in the Creation of Human Capital", American Journal of Sociology, 94, 95-120.

Coleman, J.S. (1990), Foundations of Social Theory, Cambridge: Harvard University Press.

Çalışkan, D. (2010), "Yenilikçi Oluşumlarda Sosyal Sermayenin Rolü ve Burdur İli Üzerine Bir Araştırma”, Doktora Tezi, SDÜ Sosyal Bilimleri Enstitüsü.

Dasgupta, P. \& I. Serageldin (2001), Social capital: a multifaceted perspective, World Bank Publications.

Dickey, D.A. \& A.F. Wayne (1981), "Likelihood Ratio Statistics for Autoregressive Time Series with a Unit Root", Econometrica: Journal of the Econometric Society, 49, 1057-1072.

Dincer, O.C. \& E.M. Uslaner (2010), "Trust and growth", Public Choice, 142(1-2), 59-67.

Dinda, S. (2008), "Social Capital in the Creation of Human Capital and Economic Growth: A Productive Consumption Approach", The Journal of Socio-Economics, 37(5), 20202033. 
Easterly, W. \& L. Ross (1997), “Africa's Growth Tragedy: Policies and Ethnic Divisions”, Quarterly Journal of Economics, 112(4), 1203-50.

Ekşi, H. (2009), "Sosyal Sermaye -Önemi, Üretimi ve Ölçümü Üzerine Bir Alan Araştırması”, T.C. Selçuk Üniversitesi, Sosyal Bilimler Enstitüsü, İşletme Anabilim Dalı, Yayınlanmamış Doktora Tezi, Konya.

Engle, R.F. \& W.J.G. Clive (1987), "Co-integration and Error Correction: Representation, Estimation, and Testing”, Econometrica: Journal of the Econometric Society, 55, 251276.

Feki, C. \& N. Chtourou (2014), "Social Capital and Economic Growth: Empirical Analysis of Panel Data", International Journal of Innovation and Scientific Research, 2(1), 164-176.

Fukuyama, F. (1995a), Trust: The Social Virtues and the Creation of Prosperity, The Free Press, New York.

Fukuyama, F. (1995b), "Social Capital and The Global Economy”, Foreign Affairs, 74, 89-103.

Fukuyama, F. (1999), The Great Disruption. London, Profile Books.

Fukuyama, F. (2002), "Social Capital and Development: The Coming Agenda", SAIS Review, 22, 23-37.

Glaeser, E.L. \& D.I. Laibson \& J.A. Scheinkman \& C.L. Soutter (2000), "Measuring Trust”, Quarterly Journal of Economics, 811-846.

Granger, C.W. \& P. Newbold (1974), "Spurious Regressions in Econometrics”, Journal of Econometrics, 2(2), 111-120.

Grootaert, C. \& D. Narayan \& V.N. Jones \& M. Woolcock (2004), Measuring Social- An Integrated Questionnaire, World Bank Publications, 1-53.

Hanifan, L.J. (1916), "The Rural School Community Center", Annals of the American Academy of Political and Social Science, 67, 130-138.

Healy, T. \& S. Côté (2001), The Well-Being of Nations: The Role of Human and Social Capital, Education and Skills, Organisation for Economic Cooperation and Development.

Helliwell, J. \& R. Putnam (1995), "Economic Growth and Social Capital in Italy", Eastern Economic Journal, 21(3), 295-307.

Helliwell, J.F. (1996), "Economic Growth and Social Capital in Asia", National Bureau of Economic Research, No. w5470.

Hjerppe, R. (1998), "Social Capital and Economic Growth- Government Institute for Economic Research.Measurement of Social Capital and Growth: An Economic Methodology", Fundación BBVA, 2006.

Iyer, S. \& M. Kitson \& B. Toh (2005), "Social Capital, Economic Growth and Regional Development", Regional Studies, 39(8), 1015-1040.

Johansen, S. (1988), "Statistical Analysis of Cointegration Vectors", Journal of Economic Dynamics and Control, 12(2), 231-254.

Johansen, S. \& K. Juselius (1990), "Maximum Likelihood Estimation and Inference on Cointegration with Applications to the Demand for Money", Oxford Bulletin of Economics and Statistics, 52(2), 169-210.

Karagül, M. \& S. Akçay (2002), "Ekonomik Büyüme ve Sosyal Sermaye: Ampirik Bir Kanıt”, İktisat İsletme ve Finans, 17(198), 82-90. 
Knack, S. \& P. Keefer (1995), "Institutions and Economic Performance: Cross-Country Tests Using Alternative Institutional Measures", Economics and Politics, 7, 207-227.

Knack, S. \& P. Keefer (1997), "Does social capital have an economic payoff? A cross-country investigation", The Quarterly Journal of Economics, 1251-1288.

Knack, S. (1999), "Social Capital, Growth, and Poverty: A Survey of Cross-Country Evidence", Social Capital Initiative Working Paper 7. World Bank, Social Development Department, Washington, D.C. Processed.

Knack, S. (2002), "Social Capital, Growth and Poverty: A Survey of Cross-Country Evidence”, The Role of Social Capital in Development: An Empirical Assessment, 42-82.

Knorringa, P. \& I. Van Staveren (2006), Social Capital for Industrial Development:

Operationalizing the Concept, ISS Staff Group 3: Human Resources and Local Development, UNIDO - United Nations Industrial Development Organization.

Kormendi, R.C. \& F.G. Meguire (1985), "Macroeconomic Determinants of Growth”, Journal of Monetary Economics, 16(1), 141-63.

Krishna, A. \& N. Uphoff (2002), "Mapping and Measuring Social Capital Through Assessment of Collective Action to Conserve and Develop Watersheds in Rajasthan, India", The Role of Social Capital in Development: An Empirical Assessment, 85-124.

La Porta, R. \& F. Lopez-de-Silanes \& A. Shleifer \& R.W. Vishny (1997), "Trust in Large Organisations", American Economic Review Papers and Proceedings, 87(2), 333-338.

Maki, D. (2012), “Tests for Cointegration Allowing for an Unknown Number of Breaks", Economic Modelling, 29(5), 2011-2015.

Mauro, P. (1995), “Corruption and Growth”, Quarterly Journal of Economics, 110(3), 681-712.

Neira, I. \& E. Vázquez \& M. Portela (2009), “An Empirical Analysis of Social Capital and Economic Growth in Europe (1980-2000)”, Social Indicators Research, 92(1), 111-129.

Neira, I. \& M. Portela \& E. Vieira (2010), "Social Capital and Growth in European Regions", Regional and Sectoral Economic Studies, 10(2), 19-28.

Özcan, B. (2011), “Sosyal Sermaye ve Ekonomik Kalkınma”, Yayınlanmamış Doktora Tezi, İstanbul Üniversitesi Sosyal Bilimler Enstitüsü, İstanbul.

Paldam, M. \& G.T. Svendsen (2000), “An Essay on Social Capital: Looking for Fire Behind the Smoke", European Journal of Political Economy, 16, 339-366.

Ponzetto, G.A. \& U. Troiano (2014), Social Capital, Government Expenditures, and Growth, 1-52, $<$ https://ssrn.com/abstract=2142548>, 12.01.2016.

Parts, E. (2003), "Interrelationships between Human Capital and Social Capital: Implications for Economic Development in Transition Economies", University of Tartu Economics and Business Working Paper, 2003-24.

Pérez, F. \& J. Fernandez de Guevara \& L. Serrano \& V. Montesinos (2006), "Measurement of Social Capital and Growth: An Economic Methodology", Fundacion BBWA, 1-57.

Pesaran, M.H. \& Y. Shin \& R.J. Smith (2001), "Bounds Testing Approaches to the Analysis of Level Relationships", Journal of Applied Econometrics, 16(3), 289-326.

Pfister, L. (2010), “The Effect of Social Trust on Economic Growth”, Aarhus School of Business, Aarhus University, Master of Science in International Economic Consulting, 1-63.

Phillips, P.C. \& P. Perron (1988), "Testing for a unit root in time series regression”, Biometrika, 75(2), 335-346. 
Portes, A. \& J. Sensenbrenner (1993), "Embeddedness and Immigration: Notes on the Social Determinants of Economic Action", American Journal of Sociology, 1320-1350.

Putnam, R. \& R. Leonardi \& R.Y. Nanetti (1993), “Making Democracy Work”, Princeton University Press, Princeton, NJ.

Putnam, R.D. (2001), “Social Capital, Measurement and Consequences”, Canadian Journal of Policy Research, 2, 41-51.

Raiser, M. \& C. Haerpfer \& T. Nowotny \& C. Wallace (2002), "Social Capital in Transition: A First Look at the Evidence", Sociologický Casopis/Czech Sociological Review, 693-720.

Roth, F. (2006), "Trust and Economic Growth: Conflicting Results Between Cross-Sectional and Panel Analysis", The Ratio Institute, (No. 102).

Routledge, B.R. \& J. Von Amsberg (2003), "Social Capital and Growth", Journal of Monetary Economics, 50(1), 167-193.

Rupasingha, A. \& S.J. Goetz \& D. Freshwater (2006), "The Production of Social Capital in US Counties", The Journal of Socio-economics, 35(1), 83-101.

Sabatini, F. (2006), The Empirics of Social Capital and Economic Development: A Critical Perspective, Social Science Research Network Electronic Paper Collection, $<\mathrm{ttp}: / /$ ssrn.com/abstract=879712>, 23.01.2016.

Sakai, S. (2012), "Social Capital and Regional Economy: Empirical Analysis Using Individual Data from Questionnaire Survey", Public Policy Review, 8(5), 705-736.

Salahuddin, M. \& C. Tisdell \& L. Burton \& K. Alam (2015), "Social Capital Formation, Internet Usage and Economic Growth in Australia: Evidence From Time Series Data", International Journal of Economics and Financial Issues, 5(4), 942-953.

Sciarrone, R. (2002), "The Dark Side of Social Capital: The Case of Mafia”, Workshop on Social Capital and Civic Involvement, Cornell University.

Stock, J.H. \& M.W. Watson (1993), “A Simple Estimator of Cointegrating Vectors in Higher Order Integrated Systems", Econometrica: Journal of the Econometric Society, 61(4), 783-820.

Temple, J. \& P.A. Johnson (1998), “Social Capability and Economic Growth”, Quarterly Journal of Economics, 965-990.

Whiteley, P.F. (2000), "Economic growth and social capital", Political Studies, 48(3), 443-466.

World Bank (1997), World Development Report: The State in a Changing World, New York: Oxford University Press.

Woolcock, M. \& D. Narayan (2000), "Social Capital: Implications for Development Theory, Research, and Policy", The World Bank Research Observer, 15, 225-249.

Zak, P.J. \& S. Knack (2001), “Trust and Growth”, The Economic Journal, 111(470), 295-321. 